\title{
Short Communication: The effect of water quality on the population density of Pterygoplichthys pardalis in the Ciliwung River, Jakarta, Indonesia
}

\author{
DEWI ELFIDASARI ${ }^{1, \bullet}$, FAHMA WIJAYANTI ${ }^{2, \bullet \bullet}$, HURUNIN FATHONAH MUTHMAINAH $^{2, \bullet \bullet \bullet}$ \\ ${ }^{1}$ Department of Biology, Faculty of Science and Technology, Universitas Al Azhar Indonesia. Jl. Sisingamangaraja, Kebayoran Baru, Jakarta Selatan 12110, \\ Jakarta, Indonesia. Tel.:+62-21-72792753,7690709. ‘email: d_elfidasari@uai.ac.id, v•fahmawijaya@yahoo.com, vv"huruninfathonah@gmail.com \\ ${ }^{2}$ Department of Biology, Faculty of Science and Technology, Universitas Islam Negeri Syarif Hidayatullah Jakarta. Jl. Ir. H. Juanda No. 95, Cempaka \\ Putih, Tangerang Selatan 15412, Banten, Indonesia
}

Manuscript received: 18 February 2020. Revision accepted: 13 August 2020.

\begin{abstract}
Elfidasari D, Wijayanti F, Muthmainah HF. 2020. Short Communication: The effect of water quality on the population density of Pterygoplichthys pardalis in the Ciliwung River, Jakarta, Indonesia. Biodiversitas 21: 4100-4106. The quality of waters is determined by the average value of the measured parameter range with a direct impact on aquatic biota due to pollution. The Ciliwung River is one of the polluted waters in Jakarta, which is the habitat for Pterygoplichthys pardalis (plecos catfish) that dominates the river. This study, therefore, aimed to analyze the influence of Ciliwung River quality on the density of $P$. pardalis. Data were obtained by measuring DO, $\mathrm{BOD}, \mathrm{pH}$, rainfall, temperature, water clarity, turbidity, current velocity, river depth, ammonia, and phosphate levels, as well as the fish population density. The research result showed that the density of $P$. pardalis population was greatly influenced by the DO, BOD, $\mathrm{pH}$, turbidity, and ammonia parameters of the Ciliwung River. The waters quality with the DO condition of $2.6 \mathrm{mg} / \mathrm{L}, \mathrm{BOD}$ of $1,2 \mathrm{mg} / \mathrm{L}, \mathrm{pH}$ of 7.2, the turbidity of 3.85 FTU and ammonia of $2.65 \mathrm{ppm}$ were the optimum conditions for the highest population density of $P$. pardalis in the Ciliwung River
\end{abstract}

Keywords: Ciliwung River, density, population, Pterygoplichthys pardalis, water quality

\section{INTRODUCTION}

Water quality plays an important role in the survival of aquatic biota and affects the population density. Its parameters are directly or indirectly determined by the hydrodynamic process as well as some physical and chemical factors that occur in water (Guntur et al. 2017). Besides, pollution reduces the quality of water, which has a direct impact on aquatic biota (Kisku et al. 2017; Shetty et al. 2015). The Ciliwung River originates from the Pangrango Mountain, West Java, and flows from Bogor through Depok, and ends in Jakarta Bay's estuary. The length of the Ciliwung River is $\pm 117 \mathrm{~km}$, while the watershed area is approximately $347 \mathrm{~km}^{2}$. The previous studies explained that Pterygoplichthys pardalis is the only armored catfish in the Ciliwung River (Elfidasari et al 2016; Rosnaeni et al. 2017). It is an invasive species that originated from South America, precisely North Argentina, and its population currently dominates the fish community in the Ciliwung River.

The presence of $P$. pardalis has contributed to the population decrease of other fish in the Ciliwung River. It has the characteristics of an invasive organism, such as a skilled competitor, predator, reproducing rapidly, and easily adapting to its environment (Pysek \& Richardson 2010; Hubilla et al. 2007). This condition causes its population to dominate over other fish species in the river. The abundance of $P$. pardalis is quite beneficial to the surrounding society because it can be used as raw materials for some processed food products such as fish cakes, dumplings, fish floss, and crackers (Mahdiah 2010).

The environmental quality of the water certainly influences $P$. pardalis presence in the river. However, there was no available information that explained its impact on population density. This study aimed to analyze the effect of the water quality on the $P$. pardalis population density in the Ciliwung River. The information obtained from this research is expected to serve as a material for consideration by the Jakarta city government in carrying out policies on the` sustainable management of the Ciliwung River.

\section{MATERIALS AND METHODS}

\section{Data sampling locations}

This research was done in three sampling stations, namely St1, St2, and St3. Determination of sampling location was done using a purposive sampling method, which is based on the presence of Pterygoplichthys pardalis in the Ciliwung River, Jakarta, Indonesia. St1 is located in Condet, with the rocky conditions and the river banks overgrown with trees. St2 is located in Pasar Minggu, having a wide river body and riverbank covered with trees and shrubs. The last station is St3, located in Cawang whose riversides are densely populated with many community activities. The coordinates are as follows: St1 S $06.244053^{\circ}$-E $106.862654^{\circ}$, St2 S $06.25830^{\circ}$-E $106.86040^{\circ}$, and St3 S 06.28599 $-\mathrm{E} 106.84717^{\circ}$ as shown in Figure 1. 



Figure 1: Three sampling stations along Cawang-Condet of the Ciliwung River, Jakarta, Indonesia

\section{Water quality measurements of the Ciliwung River}

The measurements of water quality were carried out at three designated sampling locations with the data sampling conducted thrice at a distance of \pm 5 meters from each other. The measured parameters were rainfall, river currents, temperature, $\mathrm{pH}$, dissolved oxygen (DO), biochemical oxygen demand (BOD) during the breakdown of organic matter in a water sample during a five day $\left(\mathrm{BOD}_{5}\right)$, river depth, clarity, turbidity, and current velocity using various methods and measurement tools as shown in Table 1 (Mainstone and Gulson 1990; Shetty et al. 2015). Phosphate $\left(\mathrm{PO}_{4}\right)$ and Ammonia $\left(\mathrm{NH}_{3}\right)$ measurements were carried out at the Integrated Laboratory Center of the Faculty of Science and Technology of UIN Syarif Hidayatullah Jakarta.

Table 1. Water quality sampling methods in the Ciliwung River, Jakarta, Indonesia

\begin{tabular}{|c|c|c|}
\hline Parameter & Unit & $\begin{array}{l}\text { Tools/methods of } \\
\text { sampling }\end{array}$ \\
\hline \multicolumn{3}{|l|}{ Physical } \\
\hline Rainfall & $\mathrm{Mm}$ & $\begin{array}{l}\text { Secondary data from } \\
\text { meteorological stations }\end{array}$ \\
\hline Temperature & ${ }^{\circ} \mathrm{C}$ & Thermometer \\
\hline River current & $\mathrm{m} / \mathrm{sec}$. & Current meter \\
\hline River depth & $\mathrm{Cm}$ & Scale stick \\
\hline Clearness & $\%$ & Secchi disk \\
\hline Turbidity & NTU & Turbidimeter \\
\hline \multicolumn{3}{|l|}{ Chemical } \\
\hline $\mathrm{pH}$ & - & $\mathrm{pH}$ meter \\
\hline Dissolved oxygen (DO) & $\mathrm{mg} / \mathrm{L}$ & BOD meter \\
\hline $\begin{array}{l}\text { Biochemical oxygen } \\
\text { demand (BOD) }\end{array}$ & $\mathrm{mg} / \mathrm{L}$ & COD meter \\
\hline Phosphate $\left(\mathrm{PO}_{4}\right)$ & $\mathrm{mg} / \mathrm{L}$ & spectrophotometer Uv-Vis \\
\hline Ammoniac $\left(\mathrm{NH}_{3}\right)$ & $\mathrm{mg} / \mathrm{L}$ & spectrophotometer Uv-Vis \\
\hline
\end{tabular}

\section{The data sampling of Pterygoplichthys pardalis density in the Ciliwung River}

The number of $P$. pardalis caught in the stocking nets of $4 \times 2 \mathrm{~m}^{2}$ in size and 2,5-inch meshes spread at three sampling stations was recorded. The nets were spread in the morning at approximately $09.00-15.00 \mathrm{WIB}$, which is the active food hunting time for members of the Loricariidae including P. pardalis (Nico 2010). Sampling was carried out three times in different weeks.

\section{The density of Pterygoplichthys pardalis in the Ciliwung River}

The density of $P$. pardalis was calculated using the following formula (Barus 2004)

$$
\begin{aligned}
& \mathrm{Di}=\mathrm{Xi} / \mathrm{Ni} \\
& \text { Index } \\
& \mathrm{Di}=\text { Density (individual } / \mathrm{m} \text { ) } \\
& \mathrm{Xi}=\text { Total number of individuals } \\
& \mathrm{Ni}=\text { Total area }
\end{aligned}
$$

The correlation between environmental parameters and the density of $P$. pardalis in the Ciliwung River

The correlation between environmental parameters and the density of $P$. pardalis was measured using the Principal Component Analysis (PCA) (Sartono et al. 2003). The measurement of the data for Analysis Factor was done using Kaiser-Meyer-Olkin (KMO) and Barletts test. KMO test was used to Measure Sampling Adequacy (MSA) for each variable (physical and chemical parameters of the waters), and Sphericity compared the correlation matrix of each variable using Barletts test (Widarjono 2010).

The formula for the KMO test is: 


$$
M O_{j}=\frac{\sum_{i \neq j} r_{i j}^{2}}{\sum_{i \neq j} r_{i j}^{2}+\sum_{i \neq j} u}
$$

Where:

$\mathrm{R}=\left[\mathrm{r}_{\mathrm{ij}}\right]$ is the correlation matrix and

$\mathrm{U}=\left[\mathrm{u}_{\mathrm{ij}}\right]$ is the partial covariance matrix.

\section{RESULTS AND DISCUSSION}

\section{The quality of the Ciliwung River waters}

The measurement results of the physical and chemical parameters at the three stations showed that the temperature was within the range of normal values, with a light intensity of 1.12-7.74 Klux, depth of $50-148 \mathrm{~cm}$, turbidity of 18.13-42.39 FTU, current velocity of $0.4-2.1 \mathrm{~m} / \mathrm{s}, \mathrm{BOD}_{5}$ of $3.8-5.7 \mathrm{mg} / \mathrm{l}, \mathrm{pH}$ of $6.5-6.9$, phosphate and ammonia values of $0.05-0.1 \mathrm{ppm}$, and 0.6-4.6 ppm, respectively(Table 2). 5-d Biochemical Oxygen Demand (BOD5) is the standardized experimental procedure to determine the relative oxygen requirements for aqueous microbes to consume organic materials in natural waters. This environmental condition is suitable for the $P$. pardalis, because this fish prefers warm waters which provide an opportunity for more sources of food and opportunities for invasion. During extreme weather (dry/cold), the $P$. pardalis tends to occupy holes in river slopes.

The optimal temperature for Pterygoplichthys $s p$ is 21 $29^{\circ} \mathrm{C}$ (Nico et al. 2012). The water current during summer increases the population of Pterygoplichthys $s p$ due to the optimal temperature, which is ideal for breeding; however, during winter/cold season, it tends to limit algae food supply and fish reproductive success (Gibbs et al. 2013). The reproduction period of plecos coincides with the large availability of phytoplankton in the water (Duarte and Araujo 2002), and an optimal condition for their growth is when the temperature is approximately $20-30^{\circ} \mathrm{C}$ (Nair et al. 2015).

The current velocity of the Ciliwung River at the time of measurement showed that the value varied among stations, with stations 1 and 3 possessing a strong current velocity at $5 \mathrm{~m} / \mathrm{s}$ and $2.1 \mathrm{~m} / \mathrm{s}$, respectively. Station 2 had a weak current velocity of $0.4 \mathrm{~m} / \mathrm{s}$ (Table 3). The current velocity of a flowing body of water, such as a river, determines the spread of organisms and the availability of food sources for aquatic biota. The stronger the current velocity is, the greater the abundance of food sources is, which also leads to the better spread of fish, and ultimately affects population density (Hockley et al. 2013; Guenard et al. 2015).

The DO at the second station had a low value of 4.66 $\mathrm{mg} / \mathrm{l}$ due to high turbidity of $42.39 \mathrm{NTU}$, and this led to the excessive consumption of oxygen by the microorganisms to mobilize organic matter (Table 2). Dissolved oxygen in water decreases with an increase in organic waste because anaerobic bacteria use it in the breaking down of organic materials. The members of the Loricariidae can live in waters with low oxygen and high organic matter contents due to their ability to take in oxygen from the air with a major food type referred to as detritus (Yossa and AraujoLima 2011).

Turbidity value is an indicator of the amount of materials, namely clay, dust, plankton, and microorganisms, suspended solid from domestic waste and activities in the water. It is negatively correlated with the value of dissolved oxygen levels. The turbidity values in three locations were 18.13-42.39 FTU (Table 2).

The $\mathrm{pH}$ value in the Ciliwung River was 6.5-6.9 (Table 2). The ideal $\mathrm{pH}$ for freshwater biota is between 6.8 and 8.5 (Tatangindatu et al. 2013). If the $\mathrm{pH}$ values are extremely low or high, the solubility of metals in the water increases, which is toxic to aquatic organisms.

The results of $\mathrm{BOD}_{5}$ measurements in the three locations showed that the pollution level was still low and categorized as good water. According to Salmin, the $\mathrm{BOD}_{5}$ value of good waters for biota ranges from 0 to $10 \mathrm{mg} / \mathrm{L}$. The first station had value of $5,7 \mathrm{mg} / \mathrm{l}$, higher than that of the third station, i.e., 4,9 mg/l (Table 2). A higher concentration indicates that the water has been polluted (Salmin 2005). The lowest $\mathrm{BOD}_{5}$ concentration was found in the second station with a value of $3,8 \mathrm{~m} / \mathrm{L}$, as shown in Table 2. However, $P$. pardalis is able to survive due to the low concentration of BOD, Chemical Oxygen Demand (COD), and Total Organic Matter (TOM) (Nugroho et al. 2014).

Table 2. Physical and chemical qualities of water in three stations in the Ciliwung River, Jakarta, Indonesia

\begin{tabular}{lccc}
\hline \multirow{2}{*}{ Physical factors of waters } & Station & St3 \\
\hline Temperature $\left({ }^{\circ} \mathrm{C}\right)$ & $28.1 \pm 1.19$ & $28.5 \pm 0.4$ & $28.4 \pm 1.16$ \\
Light Intensity (Klux) & $3.69 \pm 0.35$ & $1.12 \pm 0.51$ & $7.74 \pm 0,65$ \\
Depth (cm) & $148 \pm 0$ & $50 \pm 4.25$ & $130 \pm 43,5$ \\
Turbidity (NTU) & $29.35 \pm 4.01$ & $42.39 \pm 2.07$ & $18.13 \pm 8.49$ \\
Current Velocity (m/s) & $1.5 \pm 0.86$ & $0.4 \pm 0.28$ & $2.1 \pm 1.60$ \\
pH & $6.5 \pm 0.66$ & $6.7 \pm 0.37$ & $6.9 \pm 0.1$ \\
Biochemical Oxygen Demand (mg/L) & $5.7 \pm 0.93$ & $3.8 \pm 2.29$ & $4.9 \pm 1.37$ \\
Phosphate (ppm) & $0.05 \pm 0.01$ & $0.04 \pm 0.001$ & $0.1 \pm 0.012$ \\
Ammonia (ppm) & $0.6 \pm 0.15$ & $2.7 \pm 0.05$ & $4.6 \pm 0.95$ \\
Dissolved Oxygen (mg/L) & $5.93 \pm 0.92$ & $4.66 \pm 1,81$ & $5.23 \pm 1.50$ \\
\hline
\end{tabular}


$\mathrm{BOD}_{5}$ value increases with the increasing content of organic materials in the waters, which in turn causes the dissolved oxygen content to decrease due to decompose organism population increase (Boyd 1990). Decreased oxygen levels in the waters can be overcome by $P$. pardalis, because in anoxic conditions, potassium compounds in the fish heart play a role in reducing the quantity of blood pumped to the heart, in order to store more energy (MacCormack et al. 2003).

The phosphate concentration in this research area was 0.04-0.1 ppm (Table 2) which did not exceed the recommended value for rivers and waters The maximum value of phosphate level, recommended for rivers and waters that have ever been reported is $0,1 \mathrm{mg} / \mathrm{L}$ (Anhwange \& Edith 2012). Phosphate compounds in water are derived from natural sources such as soil erosion, animal waste, weathering of plants, destruction of organic materials, and phosphate minerals (Affan 2010). The area around the research location is densely populated, so the sources of phosphate in the river are allegedly the outcome of human activities, such as domestic waste disposal and water runoff from agricultural practices.

The ammonia concentration was high, ranging from 0.6 to $4.6 \mathrm{mg} / \mathrm{L}$ (Table 2). The maximum threshold of ammonium content in water is $1 \mathrm{mg} / \mathrm{L}$ to ensure that the fish is in a normal condition despite the pollutants in the waters (Pescod 1973). The high concentration of ammonia in the three locations was due to the activities of people living near the river, such as public bathing, washing, and toileting (Mandi Cuci Kakus - MCK). Feces of plecos in the aquatic environment increase ammonia concentrations, and it is suspected to change the translocation of nutrients, sediment characteristics, aquatic microbial, and benthic communities (Ferraris Jr 1991).

\section{Population density of Pterygoplichthys pardalis in the Ciliwung River}

The population density of $P$. pardalis at the first, second, and third stations was 58 individual $/ \mathrm{m}^{2}, 80$ individual $/ \mathrm{m}^{2}$, and 36 individual $/ \mathrm{m}^{2}$, respectively (Table 3 ), with an average of 58 individuals $/ \mathrm{m}^{2}$. The population density of $P$. pardalis in this research was greater than that in a previous study conducted in 2016, which was 22 individuals $/ \mathrm{m}^{2}$ (Halwa 2016).

The largest population density of 80 individual $/ \mathrm{m}^{2}$ was obtained at the second station, while the smallest one was found at the third station with a value of 36 individual $/ \mathrm{m}^{2}$. The second station had the greatest population density because the number of individual Poecilia reticulata and Mystacoleucus marginatus was fewer than those at the first and third stations (Hadiaty 2011).

Table 3: Population density of $P$. pardalis in three sampling stations in the Ciliwung River, Jakarta, Indonesia

\begin{tabular}{lccc}
\hline \multirow{2}{*}{$\begin{array}{l}\text { Population density of } P . \\
\text { pardalis (individual } / \mathrm{m}^{2} \text { ) }\end{array}$} & St1 & $\begin{array}{c}\text { Station } \\
\text { St2 }\end{array}$ & St3 \\
\cline { 2 - 4 } & 58 & 80 & 36 \\
\hline
\end{tabular}

This condition led to the abundance of $P$. pardalis in the station compared to Poecilia reticulata and Mystacoleucus marginatus. Its abundance is possible because of its superiority in interspecific competition in utilizing food sources with other fish in the Ciliwung River, such as Poecilia reticulata and Mystacoleucus marginatus (Hadiaty 2011). Their aggressive behavior when obtaining food in a particular location where they are abundant may change the composition of fish communities in the water. This has the potential to cause a decrease in the population of other species of fish and invertebrates in the river (Josefsson and Andersson 2001).

Population density is also influenced by the number of food sources in a body of water (De-Merona \& Ranking de-Merona 2004). According to the research conducted by Pambudi, there are 5.834 phytoplankton individuals from 53 species in the Ciliwung River. This showed that the population of fish at each station is influenced by the presence of phytoplankton (Pambudi et al. 2016). The largest population density value of 80 ind. $/ \mathrm{m}^{2}$ was found at the second station because the area had low current velocity which is optimum conditions for phytoplankton life (Odum 1988; Nair et al. 2015) At the second station, the current velocity was lower than in the first and third stations. The current velocity rate at the second station was $0.4 \mathrm{~m} / \mathrm{s}$, lower than at the first and second, i.e., $1.5 \mathrm{~m} / \mathrm{s}$ and $2.1 \mathrm{~m} / \mathrm{s}$, respectively. Another reason for the high density of $P$. pardalis at the second station was the low fishing activities carried out by the communities near the riverside. Commercial fishing activities of invasive species Pterois volitans have shown to help inhibit the growth of the fish populations in the Atlantic Sea (Barbour et al. 2011). Another cause for the high density of $P$. pardalis is the absence of predator fish because its body has several adaptations that aid it in avoiding predators. Morphological adaptation of $P$. pardalis includes having hard bones, and regenerating pectoral fins, making it impossible to be eaten by other species of fish that live in the river. P. pardalis' predators are not fish, but snakes, freshwater turtles, birds, and even humans (Anguiar and Di-Bernardo 2004; Bonini et al. 2009; Nico 2010). The presence of a particular species of fish is strongly influenced by the presence of predators (Krebs 1972).

\section{The correlation between environmental parameters and the density of Pterygoplichthys pardalis population in the Ciliwung River \\ Small KMO values showed that other variables do not} explain the correlation between pairs of parameters. The previous KMO test was not fulfilled because its value was less than 0.5 . Therefore it was necessary to eliminate the physical and chemical parameters of the Ciliwung River waters by employing the Measure Sampling Adequacy (MSA) Statistic Analysis test. The variables that had MSA value $<0.5$ was eliminated until the values of KMO, and the MSA for each variable was more than half.

The selection results using MSA values in the physical and chemical parameters of the waters show variables that were feasible to be analyzed (MSA values> 0.5). There 
were five variables, namely turbidity, $\mathrm{pH}, \mathrm{DO}, \mathrm{BOD}$, and Ammonia, which produced a KMO value of 0.646 (KMO value $<0.5)$. The results from the physical and chemical parameters showed a significance level of 0.028 (Table 4), indicating that the statistical tests for the total correlation in a matrix were significant.

The results from the analysis of the two matrix component rotations on the physical and chemical parameters of the $P$. pardalis habitat in the river successfully identified the correlation between variables with the components formed. The results showed two parameters, i.e., DO (0.958) and BOD (0.957) and three parameters, namely ammonia (0.826), turbidity (0.682), and $\mathrm{pH}(0.638)$ were highly correlated variables in component 2, (Table 5).

Interpretation of the results was conducted by observing the value of the components contained in the matrix rotation Figure 2. The value of the selected matrix component was above 0.5 and was considered to be able to explain the influencing variables. The rotating component is a correlation matrix that shows a clearer distribution of variables and is more real than the component matrix. Principal component analysis (PCA) is a technique for reducing the dimensionality of such data, increasing interpretability but at the same time minimizing information loss.

The analysis shows that the five variables in components 1 and 2 correlate with the number of individuals of $P$. Pardalis as shown in Figure 2. The conditions of the physical and chemical parameters determine the highest number of $P$. pardalis populations by 250 individuals, discovered in the Ciliwung River. The parameters that affected its density and population were DO value of $2.6 \mathrm{mg} / \mathrm{L}$, BOD of 1,2 mg/L, ammonia of 2.65 ppm, pH 7.2, and turbidity of 43.85 FTU in the waters of the river. This value provides information on the optimum conditions required for its presence in the Ciliwung River. The results of multivariate analysis (PCA) showed that e values of the physical and chemical parameters provide information that the river water has been heavily polluted. Although as a single component, the BOD value of river water within good limits value of good waters for biota ranges from 0 to $10 \mathrm{mg} / \mathrm{L}$.

Table 4. KMO Test and Bartlett's PCA results on physical and chemical parameters of the Ciliwung River waters, Jakarta, Indonesia

\begin{tabular}{llll}
\hline \multicolumn{3}{l}{ Kaiser-Meyer-Olkin Measure of Sampling } & 0.646 \\
\cline { 3 - 3 } $\begin{array}{l}\text { Adequacy. } \\
\text { Bartlett's Test of }\end{array}$ & & \\
\cline { 2 - 3 } Sphericity & Approx. & Chi- & 20.173 \\
& Square & & \\
\hline & Df & 10 \\
& Sig. & 0.028 \\
\hline
\end{tabular}

Table 5 Rotational matrix components of PCA results on physical and chemical variables of the Ciliwung River waters habitat, Jakarta, Indonesia

\begin{tabular}{|c|c|c|c|}
\hline \multirow{2}{*}{ Parameter } & & \multicolumn{2}{|c|}{ Component } \\
\hline & & 1 & 2 \\
\hline Turbidity & & -0.621 & -0.682 \\
\hline $\mathrm{pH}$ & & -0.540 & 0.638 \\
\hline Dissolved Oxygen (DO) & & 0.958 & -0.165 \\
\hline $\begin{array}{l}\text { Biochemical Oxygen } \\
\text { (BOD) }\end{array}$ & Demand & 0.957 & -0.129 \\
\hline Ammonia & & -0.167 & 0.826 \\
\hline
\end{tabular}

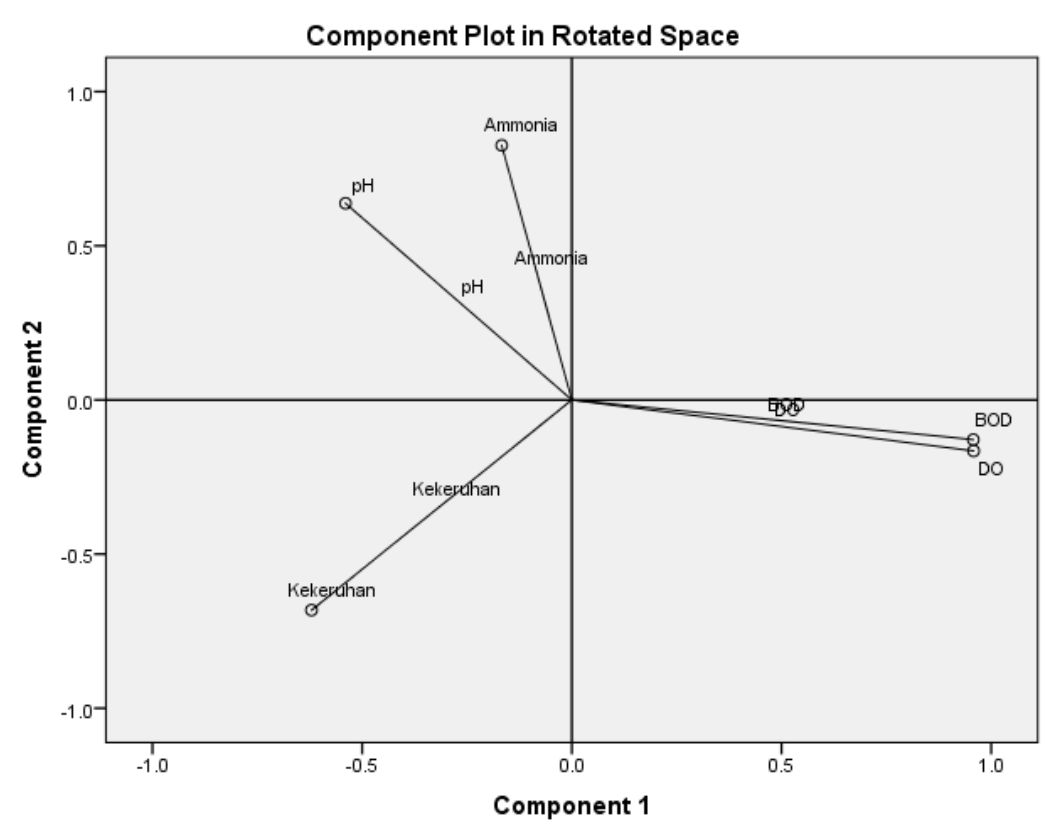

Figure 2. Effect of physical and chemical parameters to fish populations in the Ciliwung River, Jakarta, Indonesia 
The high population density of $P$. pardalis in polluted water shows that the fish can adapt to polluted aquatic environments. One cause of its adaptive abilities is the presence of additional organs in its stomach, enabling it to adapt to the state of hypoxia in waters with little dissolved oxygen (da Cruz et al. 2013). Besides, the large vascular system that functions as a lung in plecos enables it to breathe air even in hypoxic conditions (Hussan et al. 2016). Although Pterygoplichthys $s p$. breathes air, it is still influenced by environmental pH (Evans 2010). In situations where the $\mathrm{pH}$ value remains constant, there is a possibility that there is no mortality of $P$. pardalis. Generally, water quality preferences for the Loricariidae family in toxic/hypoxic conditions (dissolved oxygen values $<3 \mathrm{mg} / \mathrm{l})$ is neutral $\mathrm{pH}(7 \pm 1)($ Nico 2010).

High density leads to an increase in the number of fish that consume oxygen and the metabolic waste released (Yildiz et al. 2017; Dauda et al. 2019). Fish emit 80-90\% ammonia (N-inorganic) through the osmoregulation process, whereas $10-20 \%$ of total nitrogen is from its feces and urine. Likewise, Pterygoplichthys $s p$., which is located in freshwater in Florida, America, produces a relatively large egesta (waste/feces that are still functional) while the greatest component of its feces is organic nitrogen (Rubio et al. 2016). The small quantity of dissolved oxygen and the large concentration of ammonia in the river affect the population density of $P$. pardalis.

The feces of armored catfish affect algal biomass and productivity in their native habitat. Therefore they play an important role in controlling the abundance of algae (Power 1990). The high density of $P$. pardalis in the river causes a huge abundance of algae, which causes high turbidity. The high turbidity is also caused by dug holes for spawning habitat and egg maintenance made by Pterygoplichthys $s p$ around riparian environments (Van den Ende 2014; Maturbong 2015). The activity of excavating and making spawning tunnels by $P$. pardalis causes erosion (displacement of a mass of rock or soil), thereby causing turbidity in waters (Levin et al. 2008).

In conclusion, the water quality parameters of DO, BOD, $\mathrm{pH}$, turbidity, and ammonia of the Ciliwung River waters greatly influenced the population density of $P$. Pardalis. The quality of waters with DO of $2.6 \mathrm{mg} / \mathrm{L}$, BOD of $1.2 \mathrm{mg} / \mathrm{L}, \mathrm{pH}$ value of 7.2 , the turbidity of 3.85 FTU, and ammonia of $2.65 \mathrm{ppm}$ were the optimum conditions for the highest population density of $P$. pardalis in the Ciliwung River.

\section{ACKNOWLEDGEMENTS}

The authors are grateful to the Ministry of Research and Technology of Higher Education for the funds provided through the Directorate of Research and Community Service. The authors are also grateful to all those that helped in carrying out this study.

\section{REFERENCE}

Affan JM. 2010. Analysis of marine resource potential and water quality based on physical and chemical parameters on the east coast of Kabupaten Bangka Tengah. Spektra 10: 99-113. [Indonesian]

Anguiar LF, Di-Bernardo M. 2004. Diet and feeding behavior of Helicops infrataeniatus (Serpentes: Colubridae: Xenodontinae) in Southern Brazil. Stud Neotrop Fauna Environ 39: 7-14.

Anhwange B, Edith A. 2012. Impact assessment of human activities and seasonal variation on river Benue, within Makurdi Metropolis. Intl J Sci Technol 2: 248-254.

Barbour AB, Allen MS, Frazer TK, Sherman KD. 2011. Evaluating the potential efficacy of invasive lionfish (Pterois volitans) removals. PLoS ONE 6 (5): e19666. DOI: 10.1371/journal.pone.0019666.

Barus TA. 2004. Introduction to Limnology Studies on Terrestrial Water Ecosystem. USU Press, Medan. [Indonesian]

Bonini M, Lescano JJ, Haro JG, Leynaud GC. 2009. Diet of Hydromedusa tectifera (Testudines-Chelidae) in a mountain stream of Cordoba Province, Argentina. Amphibia-Reptilia 30: 545-554.

Boyd CE. 1990. Water quality in ponds for aquaculture. Birmingham Publishing Co, Birmingham, UK.

da Cruz AL. et al. 2013. Air-breathing behavior and physiological responses to hypoxia and air exposure in the air-breathing Loricariid fish, Pterygoplichthys anisitsi. Fish Physiol Biochem 39: 243-256.

Dauda AB, Ajadi A, Tola-Fabunmi AS, Akinwole AO. 2019. Waste production in aquaculture: source, components and management in different cultural systems. Aquac Fish 4: 81-88.

De-Merona B, Ranking de-Merona J. 2004. Food resource partitioning in a fish community of the Central Amazone floodplain. Neotrop Ichthyol 2: 75-84.

Duarte S, Araujo FG. 2002. Fecundity of the Hypostomus affinis (Siluriformes, Loricariidae) in the lakes reservoirs, Rio de Janeiro, Brazil. Revista de Biologia Tropical 50: 193-197.

Elfidasari D, Qoyyimah FD, Fahmi MR. 2016. Morphometric and meristic of common pleco (Loricariidae) on Ciliwung River watershed south Jakarta region. Intl J Adv Res 4: 57-62.

Evans DH. 2010. Freshwater fish gill ion transport: August Krogh to morpholinos and microprobes. Acta Physiologica 201: 1-11.

Ferraris JrC. 1991. Catfish in the Aquarium. Tetras Press, Morris Plains

Gibbs MA, Kurth BN, Bridges CD. 2013. Age and growth of the loricariid catfish Pterygoplichthys disjunctivus in Volusia Blue Spring, Florida. Aquat Invas 8: 207-218.

Guenard G et al. 2015. A spatially-explicit assessment of the fish population response to flow management in a heterogeneous landscape. Ecosphere 7: 1-12.

Guntur G, Yanuar AT, Sari SH, Kurniawan A. 2017. Water quality analysis based on pollution index in East Part of Surabaya Coastal area. Depik 6: 81-89. [Indonesian]

Hadiaty R. 2011. Diversity and loss of fish species in the Ciliwung River and Cisadane River. Berita Biologi 10: 491-504. [Indonesian]

Halwa A. 2016. Bioaccumulation of heavy metal $(\mathrm{Pb}, \mathrm{Cd}, \mathrm{Cr})$ in pleco flesh from upstream of Ciliwung River. [Thesis] University Islam Negeri Syarif Hidayatullah. Jakarta [Indonesian]

Hockley FA, Wilson CAME, Brew A, Cable J. 2013. Fish responses to flow velocity and turbulence in relation to size, sex, and parasite load. J R Soc Interface 11: 8-14.

Hubilla M, Kis F, Primavera J. 2007. Janitor fish Pterygoplichthys disjunctivus in the Agusan Marsh: a threat to freshwater biodiversity. J Environ Sci Manag 10: 10-23.

Hussan A, Arabinda D, Tanmoy GC. 2016. Suckermouth sailfin catfishes: a future threat to aquatic ecosystem of India. Aquacult Times 3: 1-12.

Josefsson M, Andersson B. 2001. The environmental consequences of alien species in the Swedish Lakes Malaren, Hjalmaren, Vanern and Vattern. Ambio 30: 514-521.

Kisku S et al. 2017. A cross-sectional study on water quality in relation to fish diversity of Paschim Medinipur, West Bengal, India through geoinformatics approaches. Egyptian J Aquat Res 43: 283-289.

Krebs JC. 1972. The experimental analysis of the distribution and abundance. Harper and Row Publ, New York.

Levin BA, Phuong PH, Pavlon DS. 2008. Discovery of the Amazon sailfin catfish Pterygoplichthys pardalis (Castelnau, 1855) (Teleostei: Loricariidae) in Vietnam. J Appl Ichthyol 24: 715-717.

MacCormack TJ, Treberg JR, Almeida-Val VMF, Val AL, Driedzic WR 2003. Mitochondrial K(ATP) channels and sarcoplasmic reticulum 
influence cardiac force development under anoxia in the Amazonian Armored Catfish Liposarcus pardalis. Comp Biochem Physiol A Mol Integr Physiol 134: 441-448.

Mahdiah E. 2010. The effect of the addition of binding material on the physical characteristics of otak-otak from pleco (Liposarcus pardalis) flesh. [Thesis]. Institut Pertanian Bogor, Bogor [Indonesian]

Mainstone CP, Gulson J. 1990. The effect of water quality on freshwater fish populations. National Rivers Authority, Buckinghamshire, UK.

Maturbong MR. 2015. The influence of the level of turbidity of the water on the composition of macroalgae species in Rutong Leahari water. Agricola 5: 21-31.

Nair AM, Reshma JK, Mathew A, Aswathy AJ. 2015. Effect of water quality on phytoplankton abundance in selected ponds of Nedumangad Block Panchayat, Kerala. Emer Life Sci Res 1: 35-40.

Nico L et al. 2012. Discovery of South American suckermouth armored catfish (Loricariidae, Pterygoplichthys spp.) in the Santa Fe River drainage, Suwannee Riser Basin, USA. Bioinvas Rec 1: 179-200.

Nico LG. 2010. Nocturnal and diurnal activity of suckermouth catfish (Loricariidae: Pterygoplichthys) associated with winter Florida manatees. Neotrop Ichthyol 8: 893-893.

Nugroho AA, Rudiyanti S, Haerudin. 2014. The Effectiveness of the use of broom fish to improve the quality of ish processing wastewater (depend on BOD, COD, TOM). Diponegoro J Maquares 3: 15-23.

Odum EP. 1988. Fundamentals of ecology. WB Saunders Company, Philadelphia.

Pambudi A, Priambodo TW, Noriko N, Basma. 2016. Ciliwung River phytoplankton diversity after the "Ciliwung Bersih" programme. J Al Azhar Indonesia Seri Sains dan Teknologi 3: 204-211. [Indonesian]

Pescod MB. 1973. Investigation of National Affluence and Stream Standart for Tropical Countries. U.S. Army Research and Development Group, San Fransisco.

Power ME. 1990. Resource enhancement by indirect effects of grazers: armored catfish, algae, and sediment. Ecology 71: 897-904.

Pysek P, Richardson DM. 2010. Invasive species environmental change and management and health. Ann Rev Environ Res 35: 25-55.
Rosnaeni, Elfidasari D, Fahmi MR. 2017. DNA Barcodes of the Pleco (Loricariidae, Pterygoplichthys) in the Ciliwung River. Intl J Adv Res 5: 33-45.

Rubio VY, Gibbs MA, Work KA, Bryan CE. 2016. Abundant feces from an exotic armored catfish, Pterygoplichthys disjunctivus (Weber, 1991), create nutrient hotspots and promote algal growth in a Florida spring. Aquat Invas 11: 337-350.

Salmin. 2005. Disolved Oxigen (DO) and Biological Oxigen Demand (BOD) as one indicator of water quality. Jurnal Oseana 30: 21-26.

Sartono B, Affendi FM, Syafitri UD, Sumertajaya IM, Anggraeni Y. 2003. Multiple Variable Analysis. Institut Pertanian Bogor, Bogor. [Indonesian]

Shetty A, Venkateshwarlu M, Muralidharan M. 2015. Effect of water quality on the composition of fish communities in three coastal rivers of Karnataka, India. Intl J Aquat Biol 3: 42-51.

Sinha RK, Sinha RK, Sarkar UK, Lakra WS. 2010. First record of the southern sailfin catfish, Pterygoplichthys anisitsi Eigenmann \& Kennedy, 1903 (Teleostei: Loricariidae), in India. J Appl Ichthyol 26: 606-608.

Sugiyono. 2007. Methods of Qualitative and Quantitave Research. Alfabeta, Bandung. [Indonesian]

Tatangindatu F, Kalesaran O, Rompas R. 2013. Study of water chemical physics parameters in the fish farming area in Danau Tondano, Desa Paleloan, Minahasa. Budidaya Perairan 1: 8-19. [Indonesian]

Van den Ende O. 2014. Burrowing by Sailfin Catfish (Pterygoplichthys sp.): A potential cause of erosion in disturbed environments. Aquat Nuisance Spec Res Progr 14: 1-19.

Widarjoyo A. 2010. Applied Multivariate Statistical Analysis. UPP STIM YKPN, Yogyakarta. [Indonesian]

Yildiz HY et al. 2017. Fish welfare in aquaponic systems: its relation to water quality with an emphasis on feed and faeces-A review. Water 9: 1-17. [Indonesian]

Yossa MI, Araujo-Lima C. 2011. Detritivores in two Amazonian fish species. J Fish Biol 50: 1141-1153. 